\title{
Impact of bone marrow-derived mesenchymal stromal cells on experimental xenogeneic graft-versus-host disease
}

\author{
FRANCE BRUCK ${ }^{1, *}$, LUDOVIC BELLE $^{1, *}$, CHANTAL LECHANTEUR $^{2}$, \\ LAURENCE DE LEVAL ${ }^{3}$, MURIEL HANNON ${ }^{1}$, SOPHIE DUBOIS ${ }^{1}$, \\ EMILIE CASTERMANS ${ }^{1}$, STEPHANIE HUMBLET-BARON ${ }^{1}$, SOUAD RAHMOUNI ${ }^{1}$, \\ YVES BEGUIN $^{1,2,4}$, ALEXANDRA BRIQUET ${ }^{1, \dagger} \&$ FRÉDÉRIC BARON $^{1,2,4, \dagger}$ \\ ${ }^{1}$ Groupe Interdisciplinaire de Génoprotéomique Appliquée (GIGA)-I $I^{3},{ }^{2}$ Laboratory of Cell and Genetic Therapy and \\ Departments of ${ }^{3}$ Pathology and ${ }^{4}$ Medicine, Division of Hematology, University of Liège, Liège, Belgium
}

\begin{abstract}
Background aims. Graft-versus-host disease (GVHD) is a life-threatening complication of allogeneic hematopoietic cell transplantation caused by donor T cells reacting against host tissues. Previous studies have suggested that mesenchymal stromal cells (MSCs) could exert potent immunosuppressive effects. Methods. The ability of human bone marrow derived MSCs to prevent xenogeneic GVHD in non-obese diabetic/severe combined immunodeficient (NOD/SCID) mice and in NOD/SCID/interleukin-2R $\gamma$ (null) (NSG) mice transplanted with human peripheral blood mononuclear cells (PBMCs) was assessed. Results. Injection of $200 \times 10^{6}$ human PBMCs intraperitoneally (IP) into sub-lethally (3.0 Gy) irradiated NOD/SCID mice also given anti-asialo $\mathrm{GM}_{1}$ antibodies IP 1 day prior and 8 days after transplantation induced lethal xenogeneic GVHD in all tested mice. Co-injection of $2 \times 10^{6}$ MSCs IP on day 0 did not prevent lethal xenogeneic GVHD induced by injection of human PBMCs. Similarly, injection of $30 \times 10^{6}$ human PBMCs IP into sub-lethally (2.5 Gy) irradiated NSG mice induced a lethal xenogeneic GVHD in all tested mice. Injection of $3 \times 10^{6} \mathrm{MSCs}$ IP on days 0 , 7, 14 and 21 did not prevent lethal xenogeneic GVHD induced by injection of human PBMCs. Conclusions. Injection of MSCs did not prevent xenogeneic GVHD in these two humanized mice models.
\end{abstract}

Key Words: graft-versus-host disease, GVHD, mesenchymal stromal cells, MSCs, NOD/SCID mice, NSG mice

\section{Introduction}

Acute graft-versus-host disease (GVHD), consisting of the destruction of host tissues by immune cells (mainly $\mathrm{T}$ cells) contained in the graft, has remained a major obstacle to allogeneic hematopoietic cell transplantation (1-4). In vitro or in vivo $\mathrm{T}$-cell depletion of the donor graft has been shown as the most powerful way for preventing acute GVHD, but it has been associated with increased risks of disease relapse $(4,5)$, emphasizing the need for alternative strategies.

Mesenchymal stromal cells (MSCs) are multipotent progenitors within the bone marrow capable of differentiating into various cells and tissues, such as chondrocytes, osteoblasts and adipocytes (6). Co-infusion of MSCs has been shown to facilitate engraftment of human cord blood or bone marrow hematopoietic stem cells in immunodeficient mice models when low numbers of $\mathrm{CD} 34^{+}$cells were injected (7). In addition, MSCs suppressed lymphocyte proliferation (without inducing specific tolerance) and inhibited naïve and memory $\mathrm{T}$-cell responses to their cognate antigens in vitro $(8-10)$. The ability of MSCs to inhibit T-cell alloresponses in mixed lymphoid reactions was independent of the major histocompatibility complex because inhibition was similar with "third party" haploidentical MSCs or MSCs that were autologous to the responder or stimulating lymphocytes (8-13). MSCs also exhibited immunosuppressive properties in vivo, for instance, prolonging allogeneic skin graft survival in a baboon skin graft model (14). These observations led several groups of investigators to study the ability of MSCs to prevent acute GVHD in animal models. Although some studies observed that intravenous $(15,16)$ or intraperitoneal $(17)$ co-infusion of MSCs could prevent the development of acute GVHD in mice, MSC co-infusion failed to prevent acute

*These authors contributed equally to this work.

${ }^{\dagger}$ These authors are co-senior authors.

Correspondence: Dr. Frédéric Baron, Department of Hematology, University of Liège, CHU Sart-Tilman 4000 Liège Belgium. E-mail: F.Baron@ulg.ac.be 


\section{F. Bruck et al.}

GVHD in some other murine studies $(18-20)$ as well as in a pre-clinical canine model of leukocyte antigen haploidentical transplantation (21). Nonhumanized mice studies are limited by the fact that murine and human MSCs differ in several ways: (i) in vitro immunosuppressive abilities of mouse MSCs are lower than those of human MSCs, (ii) human MSCs, but not mouse MSCs, inhibit $\mathrm{T}$ cells in vitro at least in part by secreting indoleamine 2,3-dioxygenase and (iii) mouse MSCs are more prone to undergo immortalization and transformation in culture than human MSCs $(18,22,23)$.

In humans, numerous phase I-II prospective studies suggested that MSC infusion might promote engraftment in patients given grafts from human leukocyte antigen haploidentical donors (24), cure selected patients with steroid-refractory acute GVHD (25) and prevent GVHD when co-infused with hematopoietic stem cells $(26-28)$. However, MSC infusion failed to increase (statistically significantly) the rate of sustained complete response in patients with steroid-refractory acute GVHD in a phase III randomized study (29). These discrepancies among studies stressed the need for developing animal models to study the efficacy of human MSCs as prevention or treatment of GVHD. Given that MSCs are thought to act mainly by secreting soluble factors (30) and given that MSC culture and expansion conditions influence their secretion profiles (30), models that could compare the efficacy of different human MSC preparations to prevent GVHD are urgently needed.

\section{Methods}

The study was approved by the human and animal ethics committees of the University of Liege. Written informed consent was obtained from all bone marrow and buffy coat donors in accordance with the Declaration of Helsinski.

\section{Isolation and expansion culture of human MSCs}

Bone marrow cells were obtained by bone marrow aspirates drawn from the iliac crest of adult volunteers. For most experiments, mononuclear bone marrow cells were isolated by Ficoll-Paque PLUS density gradient (Amersham Pharmacia Biotech, Uppsala, Sweden), washed twice in phosphate-buffered saline (PBS) (Lonza, Verviers, Belgium), re-suspended in human MSC medium consisting of mesenchymal stem cell growth medium (Lonza) and plated at $9 \times 10^{7}$ cells/T175 flask (Becton Dickinson, Bedford, MA, USA). After $24 \mathrm{~h}$ of culture, nonadherent cells were removed. When $70-80 \%$ confluence was achieved, adherent cells were detached and re-plated at a density of $5000 \mathrm{cells} / \mathrm{cm}^{2}$. The same conditions were used for subsequent passages.

For some experiments, MSCs were generated as previously described (28) for clinical use. Briefly, mononuclear bone marrow cells were isolated by Ficoll-Paque density gradient, seeded in sterile tissue culture flasks (BD Falcon; BD Biosciences, Bedford, MA, USA) and cultured in Dulbecco's modified Eagle's medium, low glucose (Invitrogen, Merelbeke, Belgium), with glutamate supplemented with $10 \%$ irradiated fetal bovine serum (HyClone-Perbio Science, Merelbeke, Belgium) and antibiotics (penicillin/streptomycin; Lonza). Cultures were maintained at $37^{\circ} \mathrm{C}$ in a humidified atmosphere containing $5 \%$ carbon dioxide for about 4 weeks. The medium was replaced twice every week. Cells were near confluence $(>70 \%)$ after 2 weeks of culture under these conditions. Cells were detached using irradiated trypsin-ethylenediaminetetraacetic acid (Invitrogen) and plated (passaged) at a lower density to allow further expansion. At the second passage, cells were either injected into mice or cultured for an additional one to two passages in mesenchymal stem cell growth medium as described. In an additional experiment, MSCs were activated with $100 \mathrm{IU} / \mathrm{mL}$ interferon (IFN)- $\gamma 24 \mathrm{~h}$ before injection to NSG mice.

\section{Phenotypic characterization of MSCs}

After the third passage, cultured cells were immunophenotyped using the following antibodies: allophycoerythrin (APC)-conjugated anti-CD45 (H130 clone), phycoerythrin (PE)-conjugated anti-CD90 (5E10 clone), PE-conjugated anti-CD11b (D12 clone), PE-conjugated anti-CD34 (581/CD34 clone), PE-conjugated anti-CD73 (AD2 clone), PE-conjugated anti-CD106 (51-10C9 clone), PE-conjugated anti-CD14 (M $\varphi$ P9 clone) (all from Becton Dickinson) and PE-conjugated anti-CD105 (SN6 clone) (DakoCytomation, Glostrup, Denmark). Cells were incubated with antibodies or isotype-matched control IgG (all from Becton Dickinson) for $30 \mathrm{~min}$ at $4{ }^{\circ} \mathrm{C}$ in the dark. Data were acquired on a FACSCanto II flow cytometer (BD Biosciences, Erembodegem, Belgium) and analyzed using FlowJo software (Tree Star Inc, Ashland, OR, USA). MSCs in the current study were uniformly negative for hematopoietic markers including CD11b, CD14, CD34 and CD45 antigens and positive for CD73, CD90, CD105 and CD106 antigens (data not shown).

To assess the capacity of MSCs to differentiate into fat, bone and cartilage, we cultivated them under specific induction conditions as previously described (31). In all tested cultures, lipid vacuoles, calcium deposits and chondrogenic differentiation were 
evidenced by staining with oil red $\mathrm{O}$, alizarin red, and toluidine blue, demonstrating the differentiation ability of cultured MSCs (data not shown).

\section{MSC immunosuppression assays}

In flat-bottom 96-well plates (Becton Dickinson), $5 \times 10^{3}, 1 \times 10^{4}$ or $5 \times 10^{4}$ MSCs were plated in triplicates in a total volume of $100 \mu \mathrm{L}$ of RPMI medium 1640 supplemented with $10 \%$ fetal bovine serum, $100 \mathrm{U} / \mathrm{mL}$ penicillin, $100 \mathrm{mg} / \mathrm{mL}$ streptomycin, L-glutamine ( $2 \mathrm{mmol} / \mathrm{L}$ ) (all from Lonza), $\mathrm{N}$-2-hydroxyethylpiperazine- $\mathrm{N}^{\prime}$-2-ethanesulfonic acid $(25 \mathrm{mmol} / \mathrm{L})$, sodium pyruvate $(100 \mathrm{~mol} / \mathrm{L})$, nonessential amino acid $(100 \mathrm{~mol} / \mathrm{L})$ and $5 \times 10^{-5} \mathrm{M}$ $\beta$-mercaptoethanol (all from Gibco, Merelbeke, Belgium). After 5-h incubation, MSCs were irradiated at 25 Gy using a ${ }^{137} \mathrm{Cs}$ source (GammaCell 40; Nordion, Ontario, Canada). Allogeneic human peripheral mononuclear cells (PBMCs) were isolated from buffy coat by Ficoll-Paque PLUS density gradient. PBMCs $\left(5 \times 10^{4}\right)$ were added to wells in a total volume of 200 $\mu \mathrm{L}$ containing irradiated MSCs or not containing irradiated MSCs, in the presence of anti- $\alpha \mathrm{CD} 3 / \mathrm{CD} 28$ microbeads (Invitrogen Dynal A/S, Oslo, Norway). Co-cultures without anti- $\alpha \mathrm{CD} 3 / \mathrm{CD} 28$ microbeads were used as controls. Cells were incubated at $37^{\circ} \mathrm{C}$ in $5 \%$ humidified air for 4 days. Cell cycle analyses of PBMCs stimulated with anti- $\alpha \mathrm{CD} 3 / \mathrm{CD} 28$ microbeads or not stimulated with anti- $\alpha \mathrm{CD} 3 / \mathrm{CD} 28$ microbeads and cultivated during 4 days with or without MSCs were performed using CycleTEST Plus DNA Reagent Kit (Becton Dickinson) as previously reported (32). The percentage of cells in the different phases of the cell cycle was determined with ModFit software (Becton Dickinson). In the current study, MSCs inhibited PBMC proliferation. In the absence of MSCs, the percentages of cells in $\mathrm{G}_{2} / \mathrm{M}$ phases of the cell cycle were $50 \pm 5 \%$. When MSCs were present, this percentage decreased to $43 \pm 10$ $(P=0.07)$ at a $P B M C / M S C$ ratio of $10: 1$ to reach $35 \pm$ $10(P=0.02)$ at a ratio of $10: 5$ and finally $26 \pm 3 \%$ $(P<0.0001)$ at a ratio of 1:1 (supplementary Figure 1).

Proliferation was also assessed using ${ }^{3}[\mathrm{H}]$-thymidine (PerkinElmer, Boston, MA, USA) incorporation. During 4 days, $1 \times 10^{5}$ or $1 \times 10^{6}$ PBMCs stimulated with anti- $\alpha \mathrm{CD} 3 / \mathrm{CD} 28$ microbeads or phytohemagglutinin $(10 \mu \mathrm{g} / \mathrm{mL}$; Sigma Aldrich, St. Louis, MO, USA) with or without irradiated (25 Gy) $1 \times 10^{5}$ MSCs were cultivated. To each well, $6.7 \mathrm{Ci} / \mathrm{mmol}(248 \mathrm{GBq} / \mathrm{mmol})$ of ${ }^{3}[\mathrm{H}]$-thymidine was added in $25 \mu \mathrm{L} 16 \mathrm{~h}$ before the end of the co-culture. The cells were harvested automatically on a glass filter, using a Tomtec harvesting machine (Hamden, CT, USA) on day 4. Thymidine incorporation was expressed as counts per minute. In the presence of irradiated MSCs, we observed that PBMC proliferation was significantly reduced at both MSC/PBMC ratios $(P<0.0001)$ (Supplementary Figure 1C).

\section{Development of humanized murine models of GVHD}

To induce GVHD, non-obese diabetic/severe combined immunodeficient (NOD/SCID) mice received on day -1 a single dose of 3.0 Gy total body irradiation (TBI) using ${ }^{137}$ Cs source and injected IP with $20 \mu \mathrm{L}$ of anti-asialo $\mathrm{GM}_{1}$ (aASGM1) antibody (Wako Chemicals USA, Dallas, TX, USA). PBMCs were isolated from buffy coats by centrifugation over Ficoll-Paque PLUS density gradient and washed twice in PBS. Cells were counted with an HORIBA ABX automatic cell counter (ABX Hematology, Montpellier, France) and re-suspended in PBS at a concentration of $200 \times 10^{6} / 400 \mu \mathrm{L}$. Cell suspensions were injected IP into mice under sterile conditions on day 0 . Transplanted mice received a second dose of $20 \mu \mathrm{L}$ of aASGM1 antibody administered IP 8 days later.

\section{NSG mice}

NOD/SCID/interleukin-2R $\gamma$ (null) (NSG) (The Jackson Laboratory, Bar Harbor, ME, USA) were irradiated with 2.5 Gy TBI using a ${ }^{137}$ Cs source 1 day before intraperitoneal injection of human PBMCs obtained from buffy coats from healthy volunteers. PBMCs were isolated as described previously. Cells were counted with a HORIBA ABX automatic cell counter and re-suspended in PBS. Four doses of human PBMCs $\left(10 \times 10^{6}, 20 \times 10^{6}\right.$, $30 \times 10^{6}$ or $50 \times 10^{6}$ ) were infused to test their ability to induce xenogeneic GVHD.

Mice were tagged on day 0 , weighed twice weekly, and assessed for symptoms of xenogeneic GVHD including weight loss, posture (hunching), reduced activity, ruffled fur texture, anemia and tachypnea. Mice with terminal GVHD were sacrificed and examined for human cell infiltration by flow cytometry, histologic analysis and immunochemistry.

\section{Capacity of MSCs to prevent or to treat GVHD in NOD/SCID and NSG mice models}

To assess the ability of MSCs to prevent GVHD in our models, NOD/SCID or NSG mice received $2 \times 10^{6}$ MSCs or $3 \times 10^{6}$ MSCs from passages three or four IP at the time of PBMC injection. For the NSG model, mice received three additional injections of MSCs (total number of cells, $12 \times 10^{6}$ MSCs) at weekly intervals. In a second set of experiments, NSG mice received $3 \times 10^{6} \mathrm{MSCs}$ at 
passages three or four intravenously at the time of PBMC injection and at weekly intervals for three administrations (total dose, $9 \times 10^{6} \mathrm{MSCs}$ ). Finally, in an additional experiment, some NSG mice were given intraperitoneal sirolimus (Rapamune at $1.5 \mathrm{mg} / \mathrm{kg}$ from day 0 to day 7 and $1 \mathrm{mg} / \mathrm{kg}$ from day 8 to day 21; Pfizer, New York, NY, USA).

\section{Flow cytometry analyses for detection of human engraftment}

At the time of necropsy, peripheral blood, spleen and bone marrow were harvested and analyzed by flow cytometry. Splenocytes were obtained by crushing the spleen, and bone marrow was obtained by flushing the femurs and tibiae. Cells were counted in a HORIBA ABX. To demonstrate human engraftment, a first gate on living cells was made using the SSC/FSC dot plot, and the percentage of human $\mathrm{CD} 45^{+}$cells (identified using the anti-human CD45 APC or PE-Cy7 (clone, HI30; eBioscience, San Diego, CA, USA) among total living cells was calculated (31). The following antibodies specific for human cell surface antigens were used: APC or fluorescein isothiocyanate-conjugated anti-CD3 (SK3 clone; Becton Dickinson), peridin chlorophyll protein-conjugated (SK3 clone; Becton Dickinson) or efluor 450 (RPA-T4 clone; eBioscience) antiCD4, PE-conjugated anti-CD8 (HIT8a clone; Becton Dickinson), PE-conjugated anti-CD25 (BC96 clone; eBioscience). Cells $\left(1.5 \times 10^{6}-2 \times 10^{6}\right.$ cells/ sample) were incubated with antibodies or isotypematched control IgG (all MOPC 21 clone; Becton Dickinson) for $30 \mathrm{~min}$ at $4^{\circ} \mathrm{C}$ in the dark. The resulting cell pellet was depleted of erythrocytes using a ammonium chloride solution ( $\mathrm{pH}$ 7.2). Cells were washed twice with $\mathrm{PBS} / 1 \%$ fetal bovine serum (Lonza) and fixed in PBS $/ \%$ formalin (Sigma Aldrich). Human intracellular transcription factor forkhead box passage 3 (Foxp3) staining kit containing AlexaFluor 488 anti-Foxp3 (206D clone), isotype-matched control IgG, Fix/Perm solution, and Fix/Perm buffer was purchased from BioLegend (San Diego, CA, USA). Foxp3 intracellular staining was achieved as described by the manufacturer's instructions. Data were acquired on a FACSCanto II flow cytometer (Becton Dickinson) and analyzed with FlowJo software 7.0 (Tree Star Inc).

\section{Histology and immunochemistry}

Small intestine, liver, lungs and skin were harvested, washed with PBS, fixed in 10\% formalin (Sigma Aldrich) and routinely processed for paraffin embedding. For all organs, 5- $\mu \mathrm{m}$ sections were stained with hematoxylin and eosin for histologic examination. Immunostaining was performed on $5-\mu \mathrm{m}$ sections manually for CD45 (2B11+PD7/26 clone; DakoCytomation) using a standard indirect two-step labeling method or on a BenchMark XT autostainer (Ventana Medical Systems, Tucson, AZ, USA) for CD3 (clone PS1; Novocastra/Leica, Newcastle Upon Tyne, UK), CD4 (clone 1F6; Novocastra/Leica) and CD8 (clone C8/144B; DakoCytomation). Staining with sirius red was performed to evaluate fibrosis in the liver, skin and lungs of a NSG mouse who developed signs of chronic GVHD after intraperitoneal infusion of PBMCs and MSCs.

\section{Detection and quantification of MSCs engraftment in NOD/SCID mice}

NOD/SCID mice irradiated with 3.0 Gy TBI on day -1 received $2 \times 10^{6}$ MSCs IP on day 0 . aASGM1 antibodies $(20 \mu \mathrm{L})$ were injected IP on day -1 and day 8 after MSC infusion. Mice were sacrificed on day 1, 7 or 14. Lungs, liver, kidneys, small intestine, spleen and bone marrow were collected and frozen. Homing of MSCs was studied by quantitative real-time polymerase chain reaction (PCR) (using Power SYBRGreen PCR master mix; Applied Biosystems, Foster City, CA, USA; and ABI PRISM 7700; Altera, Norwalk, CT, USA) as previously reported (31) (see Supplementary text).

Detection and quantification of engraftment or homing of MSCs in NSG mice with xenogeneic GVHD

NSG mice were irradiated with 2.5 Gy TBI on day -1 then received $3 \times 10^{6}$ MSCs from male donors at the time of injection of $30 \times 10^{6}$ PBMCs from female donors and at weekly intervals for four administrations (total dose, $12 \times 10^{6} \mathrm{MSCs}$ ). Mice with terminal GVHD were euthanized, and peripheral blood, lungs, liver, small intestine, colon, spleen, bone marrow, peritoneum and peritoneal fluid were collected and frozen. Genomic DNA was extracted as described previously. MSC homing was analyzed by sex-determining region Y (SRY) TaqMan realtime PCR after genomic DNA amplification by PCR (nested PCR) as previously reported by Lo et al. (33).

\section{CDR3 spectratyping (immunoscope)}

To characterize better T-cell expansion in our models of xenogeneic GVHD, T-cell receptor (TCR) $\beta$ chain CDR3 spectratyping analyses were performed on PBMCs before injection into mice and on cells collected on day 13 from spleens of four NOD/SCID mice given $200 \times 10^{6}$ human PBMCs IP after 3.0 Gy irradiation (cells from the different 
mice were pooled before RNA extraction) or from spleens of five NSG mice given $30 \times 10^{6}$ human PBMCs IP after 2.5 Gy irradiation (cells from the different mice were pooled before RNA extraction) as previously reported $(34,35)$. The overall complexity within a TCR $\mathrm{V}_{\beta}$ subfamily was determined by counting the number of peaks (intervals of three nucleotides) per subfamily.

\section{Serum cytokine levels (immunoscope)}

The concentration of human IL-2, IL-4, IL-6, IL-8, IL-10, IL-15, IL-17, tumor necrosis factor (TNF)$\alpha$ and IFN- $\gamma$ were determined in mice serum using Bio-Plex Pro Human Cytokine 9-plex Assay (Biorad Laboratories, Nazareth Eke, Belgium). The experiments were performed according to the manufacturer's recommendation, and results were acquired on Bio-Plex System and analyzed with Bio-Plex Manager Software 4.0 (Biorad Laboratories).

\section{Statistical analysis}

Statistical analyses were performed with the GraphPad Prism 5.00 Software (GraphPad Software, Inc, San Diego, CA, USA). The Mann-Whitney test was used to assess the impact of MSCs on cell proliferation in vitro, the cytokine levels in NSG mice on day 8 after transplantation and the percentages of human cells at necropsy between MSC and control mice. Survival curves were modeled using the KaplanMeier methods. Comparisons between groups were made with the log-rank test. All $P$ values were two sided. $P$ values $<0.05$ were considered as statistically significant.

\section{Results}

NOD/SCID mice model of xenogeneic GVHD

The homing capacity of MSCs to several tissues was tested at three different times. MSCs were detected in the liver, kidney and spleen of one of three tested mice and in the small bowel of another mouse 24 hours after intraperitoneal infusion of MSCs (Supplementary Table I). MSCs were detected in the bone marrows of all tested mice and in the spleen, kidneys, small bowel, liver and lungs in two of four, two of four, two of four, one of four and one of four mice 7 days after MSC infusion. Finally, MSCs were observed in the bone marrow of three of four mice and in the spleen or kidneys or both of three of four mice 14 days after MSC infusion. These results suggest that MSCs injected IP could migrate to different organs but perhaps homed preferentially to the bone marrow.
In two independent experiments of three NOD/SCID mice each, mice were irradiated at 3.0 Gy and administered aASGM1 antibody IP 1 day before and 8 days after being IP transplanted with $2 \times 10^{8}$ human PBMCs. In the first experiment, mice died on days 10, 13 and 14; in the second experiment, two mice died on day 8 and one mouse died on day 7 after transplantation. At the time of necropsy, human chimerism levels (human CD45 cells) in the five mice surviving $\geq 8$ days were $61 \%$ (range, $21-92 \%)$ in the spleen $(\mathrm{n}=5)$ and $6 \%$ (range, $1-24 \%)$ in the bone marrow $(\mathrm{n}=5)$.

In a third experiment, we compared TCR $\mathrm{V}_{\beta}$ repertoire in PBMCs before injection into NOD/ SCID mice and in spleen cells collected from NOD/ SCID mice 13 days after intraperitoneal PBMC infusion. The number of peaks in each family was comparable among PBMCs before injection (median of 10 peaks $/ \mathrm{V}_{\beta}$ family) and among spleen cells 13 days after infusion (median of 11 peaks $/ \mathrm{V}_{\beta}$ family), demonstrating a homogeneous T-cell expansion.

In a first set of experiments, we assessed the ability of human MSCs $\left(2 \times 10^{6}\right.$ cells $)$ IP co-transplanted with human PBMCs $\left(2 \times 10^{8}\right.$ cells $)$ to prevent lethal GVHD in NOD/SCID mice given 3.0 Gy TBI on day -1 and aASGM1 antibody on days -1 and 8 after transplantation. All mice given MSCs/PBMCs $(\mathrm{n}=17)$ and all control-PBMC mice (given PBMCs alone, $\mathrm{n}=26$ ) showed signs of GVHD, such as anemia, loss of locomotion and weight loss and died within the first 30 days after transplantation (Figure 1A). At the time of necropsy, both groups of mice had similar infiltration by human cells in the blood (median of human CD45 $5^{+}$ cells was $74 \%$ [range, 34-96\%] in MSC/PBMC mice versus $86 \%$ [range, 24-95\%] in PBMC mice), in the spleen (91\% [range, 38-98\%] in MSC/PBMC mice versus $93 \%$ (range, 36-98\%) in PBMC mice) and in the bone marrow (17\% [range, 2-74\%] in MSC/PBMC mice versus $26 \%$ [range, $1-59 \%$ ] in PBMC mice) (Figure 1B). The frequency of Foxp3 ${ }^{+}$ cells among total human $\mathrm{CD} 45^{+} \mathrm{CD} 3^{+} \mathrm{CD} 4^{+}$cells was similar in $\mathrm{MSC} / \mathrm{PBMC}$ mice compared with PBMC mice (7\% [range, 6-9\%] versus 7\% [range, $3-12 \%$ ] in the spleen and $6 \%$ [range, $2-8 \%$ ] versus $7 \%$ [range, $2-12 \%$ ] in the blood (Figure 1C).

In a second set of experiments, we investigated whether intravenous infusion of MSCs $\left(2 \times 10^{6}\right.$ cells) on day 0 could prevent xenogeneic GVHD in NOD/SCID mice given 3.0 Gy TBI on day -1 , human PBMCs $\left(2 \times 10^{8}\right.$ cells)IP on day 0 , and aASGM1 antibodies on days -1 and 8 after transplantation. As observed with intraperitoneal injection of MSCs, intravenous infusion of MSCs failed to prevent GVHD, with MSC/PBMC mice $(\mathrm{n}=4)$ 

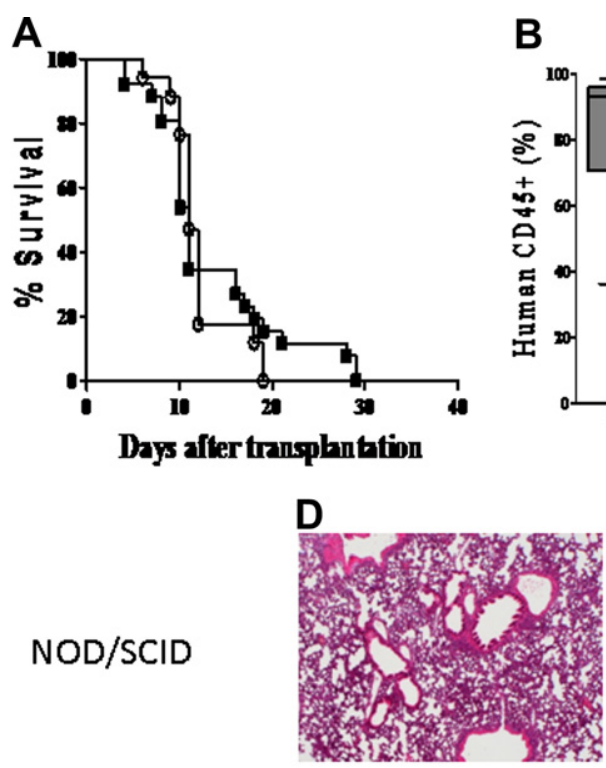

G

NOD/SCID+ MSC
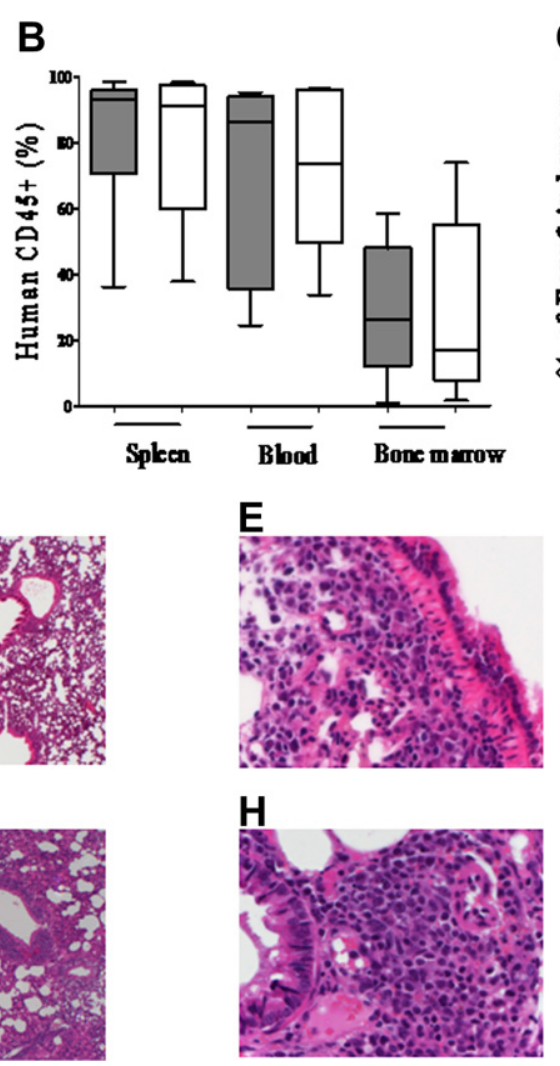
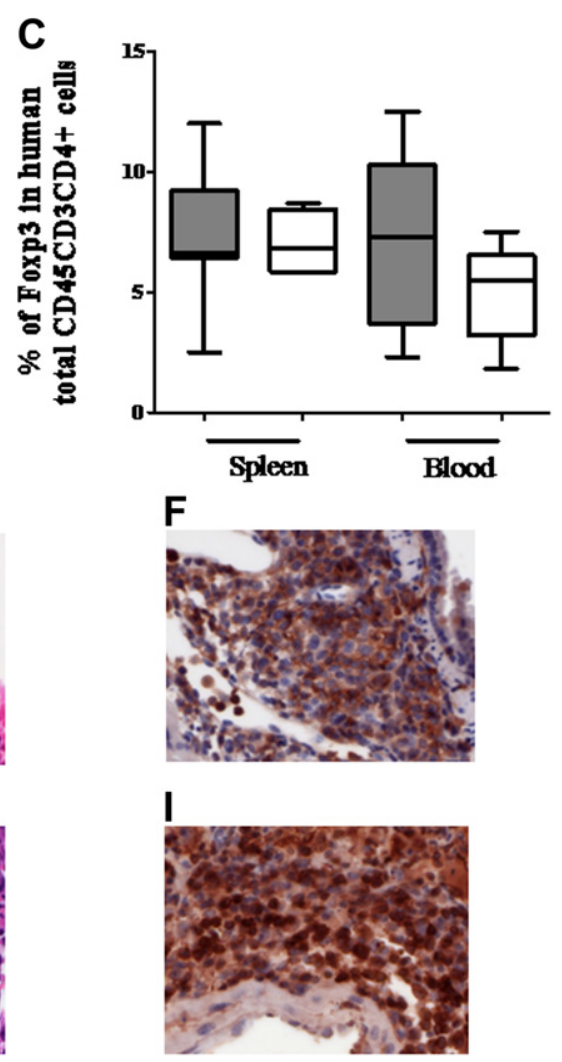

Figure 1. Impact of a single intraperitoneal infusion of MSCs on xenogeneic GVHD in NOD/SCID mice. NOD/SCID mice irradiated with 3.0 Gy on day -1 received $2 \times 10^{8}$ PBMCs IP on day 0 with or without $2 \times 10^{6}$ MSCs also infused IP. (A) Overall survival in mice given MSCs (open circles, $n=17$ ) or not given MSCs (black squares, $n=26$ ). (B) Percentage of human CD45 $5^{+}$cells in spleen ( $n=19$ in PBMC arm vs. $\mathrm{n}=11$ in MSC arm), blood ( $\mathrm{n}=14$ in PBMC arm vs. $\mathrm{n}=8$ in MSC arm) or bone marrow $(\mathrm{n}=16$ in PBMC arm vs. $\mathrm{n}=11$ in MSC arm) of mice given MSCs (gray bars) or not given MSCs (white bars). (C) Percentage of human Foxp $3^{+}$cells among total human $\mathrm{CD} 45^{+} \mathrm{CD}^{+} \mathrm{CD}^{+}$cells in spleen ( $\mathrm{n}=7$ in PBMC arm vs. $\mathrm{n}=4$ in MSC arm) and blood ( $\mathrm{n}=5$ in PBMC arm vs. $\mathrm{n}=5$ in $M S C$ arm) of mice given MSCs (gray bars) or not given MSCs (white bars). Horizontal lines represent median values in each group. (D-I) Microscopic features of the lungs at the time of necropsy in control (D-F) versus MSC mice (G-I); at low magnification (D and G, hematoxylin and eosin, $\times 50$ ), lymphoid infiltrates with a perivascular and peribronchial distribution were observed in both groups; at high magnification ( $\mathrm{E}$ and $\mathrm{H}$, hematoxylin and eosin, $\times 400$ ), the infiltrates were cytologically pleomorphic with a high proportion of large cells displaying mitotic activity; immunostaining with anti-human-CD3 showed a high proportion of $\mathrm{CD}^{+}$cells of donor origin (immunoperoxidase, $\times 400$ ).

dying on days $4,6,12$ and 12 after transplantation and control mice $(\mathrm{n}=6)$ dying on days $6,9,10,10$, 10 and 11 after transplantation. Mice in the two groups showed similar infiltration by human cells in the blood, bone marrow and spleen (data not shown).

\section{NSG mice model of xenogeneic GVHD}

Given that MSC infusion administered at a MSC/ PBMC ratio of 1:100 failed to prevent xenogeneic GVHD in NOD/SCID mice, we developed a second model of xenogeneic GVHD in NSG mice that were previously shown to be the immunodeficient mouse strain allowing the highest engraftment of human cells (36), with the aim of administering MSCs at a higher MSC/PBMC ratio.

We first determined the minimum number of human PBMCs to transplant in 2.5-Gy irradiated
NSG mice that could induce reproducible lethal GVHD within the first 25 days after transplantation with a high percentage $(\geq 10 \%)$ of human infiltration in the bone marrow. To do so, 20 NSG mice received 2.5 Gy TBI on day -1 followed by intraperitoneal infusion of human PBMCs on day 0 at $10 \times 10^{6}(\mathrm{n}=5), 20 \times 10^{6}(\mathrm{n}=5), 30 \times 10^{6}(\mathrm{n}=5)$ or $50 \times 10^{6}(\mathrm{n}=5)$ PBMCs per mouse. As shown in Figure 2, mice injected IP with $30 \times 10^{6}$ human PBMCs died 14-24 days after transplantation with signs of GVHD and a high percentage of human lymphocyte infiltration in the bone marrow (Table I). We chose these conditions to test the ability of MSC co-transplantation to prevent xenogeneic GVHD in this model.

In a second experiment, we compared TCR $\mathrm{V}_{\beta}$ repertoire in PBMCs before injection into NSG mice and in spleen cells collected from NSG mice $(n=5)$ 13 days after intraperitoneal infusion of PBMCs. The 


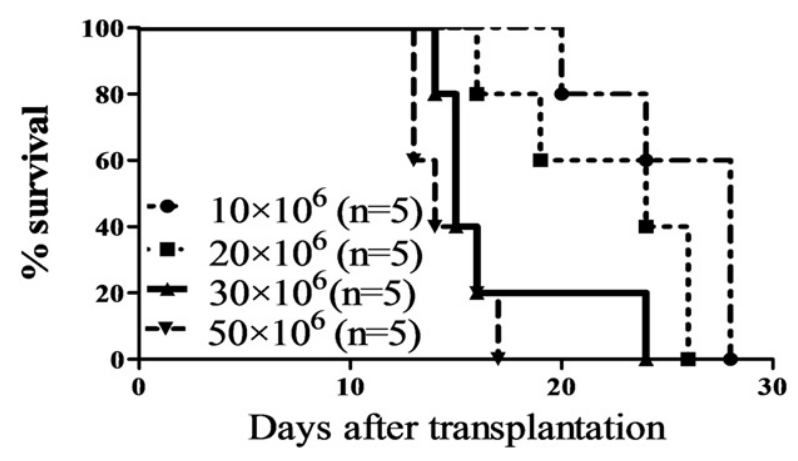

Figure 2. Survival of NSG mice according to the number of human PBMCs infused IP. NSG mice were irradiated with 2.5 Gy TBI 1 day before intraperitoneal injection of $10 \times 10^{6}(\mathrm{n}=5)$, $20 \times 10^{6}(\mathrm{n}=5), 30 \times 10^{6}(\mathrm{n}=5)$ or $50 \times 10^{6}(\mathrm{n}=5)$ PBMCs. Median survival time in each group was 28 days, 24 days, 15 days and 14 days $(P<0.01)$.

number of peaks in each family was comparable among PBMCs before injection (median of 10 peaks $/ \mathrm{V}_{\beta}$ family) and among spleen cells 13 days after infusion (median of 10 peaks $/ \mathrm{V}_{\beta}$ family), demonstrating homogeneous T-cell expansion (Figure 3).

In a first set of experiments, we assessed the ability of intraperitoneal infusion of $3 \times 10^{6}$ human MSCs on days $0,7,14$ and 21 to prevent GVHD in NSG mice irradiated on day -1 at 2.5 Gy and given $30 \times 10^{6}$ human PBMCs IP on day 0 . As shown in Figure $4 \mathrm{~A}$, there was a slight survival advantage in mice given PBMCs and MSCs $(\mathrm{n}=26$, median survival of 24 days) compared with control mice given human PBMCs alone ( $\mathrm{n}=24$, median survival of 20.5 days, $P=0.03$ ), but eventually all but one of the MSC/PBMC mice died of GVHD within the first 62 days after transplantation (Figure 4A). The mouse that survived $>100$ days had signs of chronic GVHD with fur loss that started from day 60 and skin fibrosis (Supplementary Figure 2). At the time of necropsy, MSC/PBMC mice and control mice had similar infiltration by human cells in the peripheral blood (median of human $\mathrm{CD} 45^{+}$cells was $90 \%$ [range, 46-98\%] in MSC mice versus 86\% [range, 42-98\%] in control mice), in the spleen (90\% [range, 37-99\%] in MSC mice versus 91\% [range, $31-98 \%$ ] in control mice) and in the bone marrow (30\% [range, 4-95\%] in MSC mice versus 39\% [range, 5-93\%] in control mice) (Figure 4B-I). The median frequency of $\mathrm{Foxp}^{+}$cells among human $\mathrm{CD} 45^{+} \mathrm{CD}^{+} \mathrm{CD}^{+}$cells infiltrating the spleen was $3 \%$ (range, $0.2-10 \%$ ) in MSC/PBMC mice versus $2 \%$ (range, $0.5-6 \%$ ) in control mice, 3\% (range, $0.4-15 \%$ ) in $\mathrm{MSC} / \mathrm{PBMC}$ mice versus $2 \%$ (range, $0.4-9 \%)$ in control mice for cells present in the peripheral blood and 5\% (range, 1-9\%) in MSC/

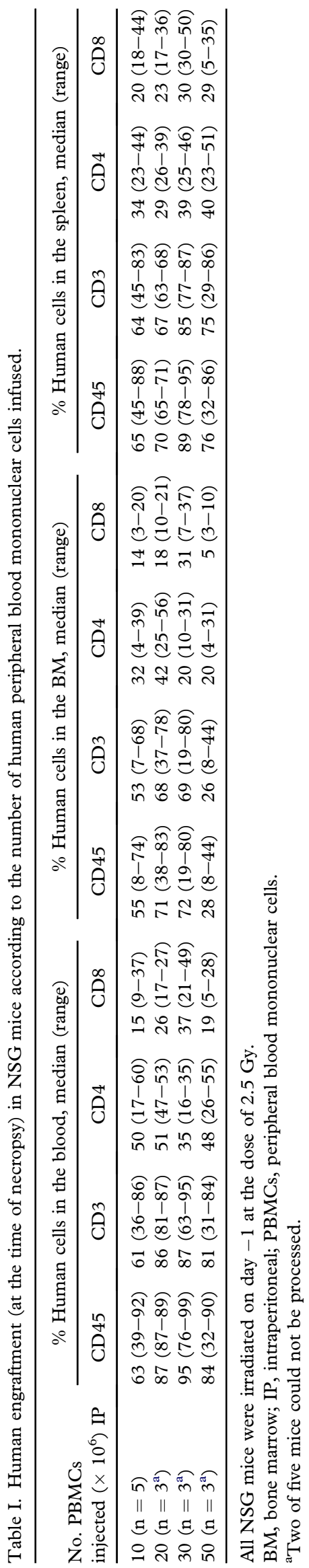




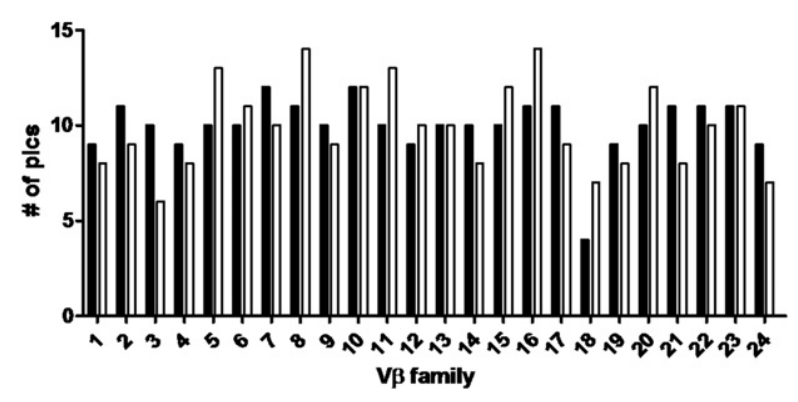

Figure 3. TCR $\mathrm{V}_{\beta}$ repertoire in PBMCs before injection into NSG mice and in spleen cells collected from five NSG mice 13 days after intraperitoneal PBMC infusion. NSG mice were irradiated at 2.5 Gy the day before PBMC injection. The number of peaks in each family was comparable among PBMCs before injection (black columns) and among spleen cells (white columns) 13 days after infusion

PBMC mice versus $2 \%$ (range, $0-8 \%$ ) in control mice for cells infiltrating the bone marrow. Microscopic examination of the tissue sections showed extensive lymphoid infiltrates with a perivascular and peribronchial distribution in the lung and in portal tracts of the liver. Cytologically, the infiltrates were pleomorphic with a high proportion of large cells displaying mitotic activity. Immunohistochemistry performed on lung sections confirmed $\mathrm{CD}^{+}{ }^{+} \mathrm{T}$-cell lymphoid infiltrates comprising an admixture of $\mathrm{CD} 4^{+}$and $\mathrm{CD} 8^{+}$cells.

In an additional experiment including 27 NSG mice, we analyzed the impact of MSC activation by IFN- $\gamma$ and the impact of a combination of MSCs with sirolimus administration on xenogeneic GVHD and on serum cytokine levels 8 days after PBMC infusion (1 day after the second intraperitoneal MSC injection in mice given MSC). All NSG mice were irradiated at $2.5 \mathrm{~Gy}$ on day -1 and given $30 \times 10^{6}$ PBMCs IP on day 0. Five NSG mice did not receive any MSCs (control mice), six mice were given $3 \times 10^{6}$ MSCs infused IP on days $0,7,14$ and 21 (MSC mice), eight mice were given $3 \times 10^{6} \mathrm{MSCs}$ infused IP on days $0,7,14$ and 21 and intraperitoneal sirolimus (Rapamune), $1.5 \mathrm{mg} / \mathrm{kg}$ from day 0 to day 7 and $1 \mathrm{mg} / \mathrm{kg}$ from day 8 to day 21 after transplantation (MSC\&Sir mice) and eight mice were given $3 \times 10^{6} \mathrm{IFN}-\gamma$ activated MSCs infused IP
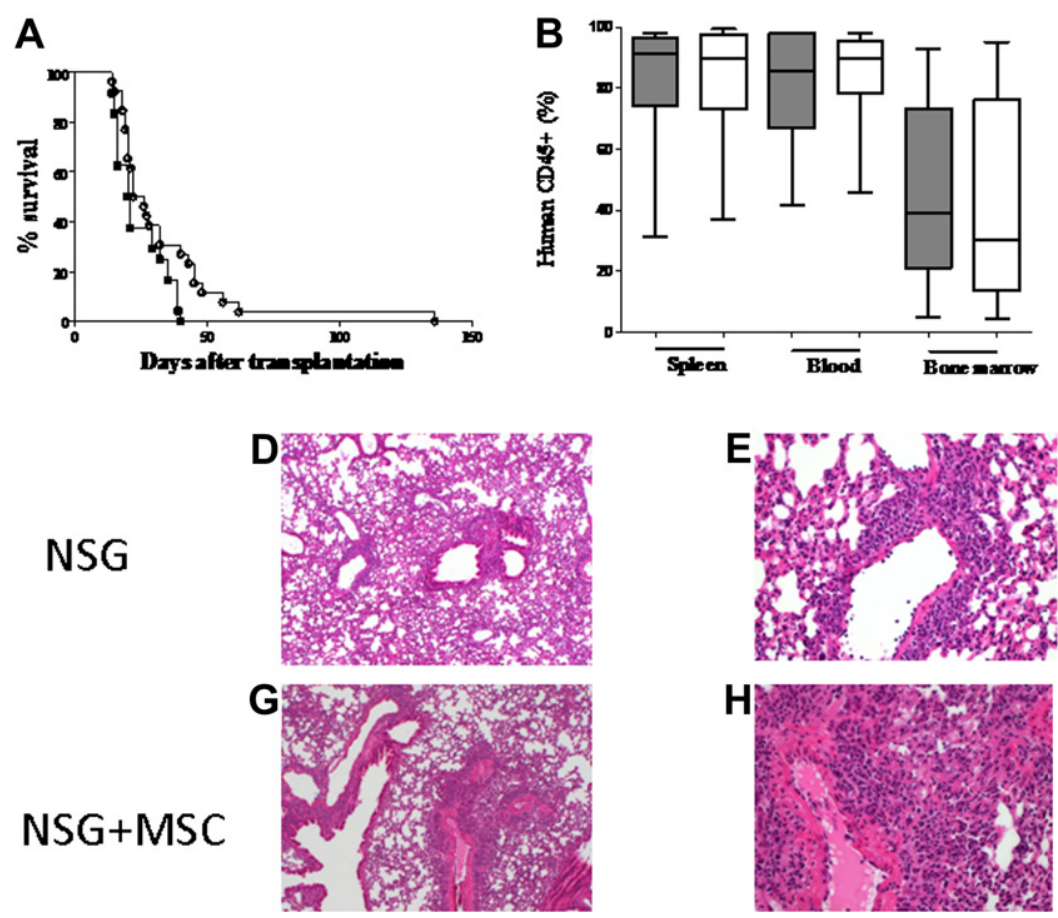

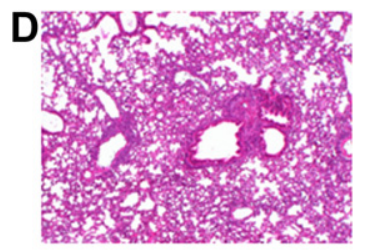

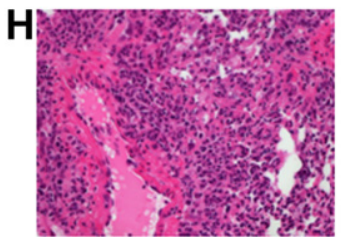
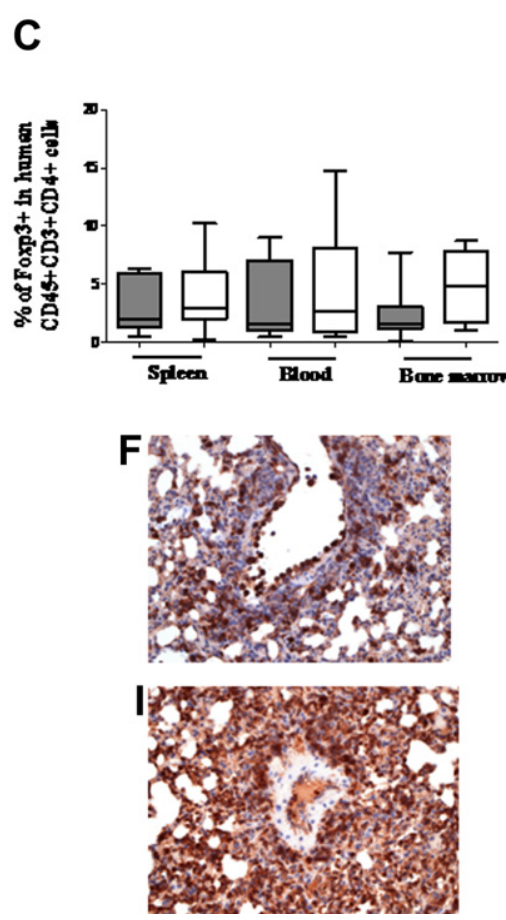

Figure 4. Impact of intraperitoneal infusion of MSCs on xenogeneic GVHD in NSG mice. NSG mice irradiated at 2.5 Gy on day -1 received $3 \times 10^{7}$ PBMCs IP on day 0 with or without $3 \times 10^{6}$ MSCs also infused IP on days $0,7,14$ and 21 . (A) Overall survival in mice given MSCs (open circles, $\mathrm{n}=26$ ) or not given MSCs (black squares, $\mathrm{n}=24$ ). (B) Percentage of human CD45 $5^{+}$cells in spleen $(\mathrm{n}=18$ in PBMC arm vs. $\mathrm{n}=12$ in MSC arm), blood ( $\mathrm{n}=17$ in PBMC arm vs. $\mathrm{n}=11$ in MSC arm) or bone marrow ( $\mathrm{n}=18$ in PBMC arm vs. $\mathrm{n}=9$ in $M S C$ arm) of mice given MSCs (gray bars) or not given MSCs (white bars). (C) Percentage of human Foxp $3^{+}$cells among total human $\mathrm{CD} 45^{+} \mathrm{CD} 3^{+} \mathrm{CD} 4^{+}$ cells of spleen ( $\mathrm{n}=7$ in PBMC arm vs. $\mathrm{n}=4$ in MSC arm) and blood ( $\mathrm{n}=5$ in PBMC arm vs. $\mathrm{n}=5$ in MSC arm) of mice given MSCs (gray bars) or not given MSCs (white bars). Horizontal lines represent median values of each group. (D-I) Microscopic features of the lungs at the time of necropsy in control (D-F) versus MSC mice (G-I); at low magnification (D and G, hematoxylin and eosin, $\times 50$ ), lymphoid infiltrates with a perivascular and peribronchial distribution were observed in both groups; at high magnification ( $\mathrm{E}$ and $\mathrm{H}$, hematoxylin and eosin, $\times 200$ ), the infiltrates were cytologically pleomorphic with a high proportion of large cells displaying mitotic activity; immunostaining with anti-human-CD3 showed a high proportion of $\mathrm{CD}^{+}$cells of donor origin (immunoperoxidase, $\times 200$ ). 

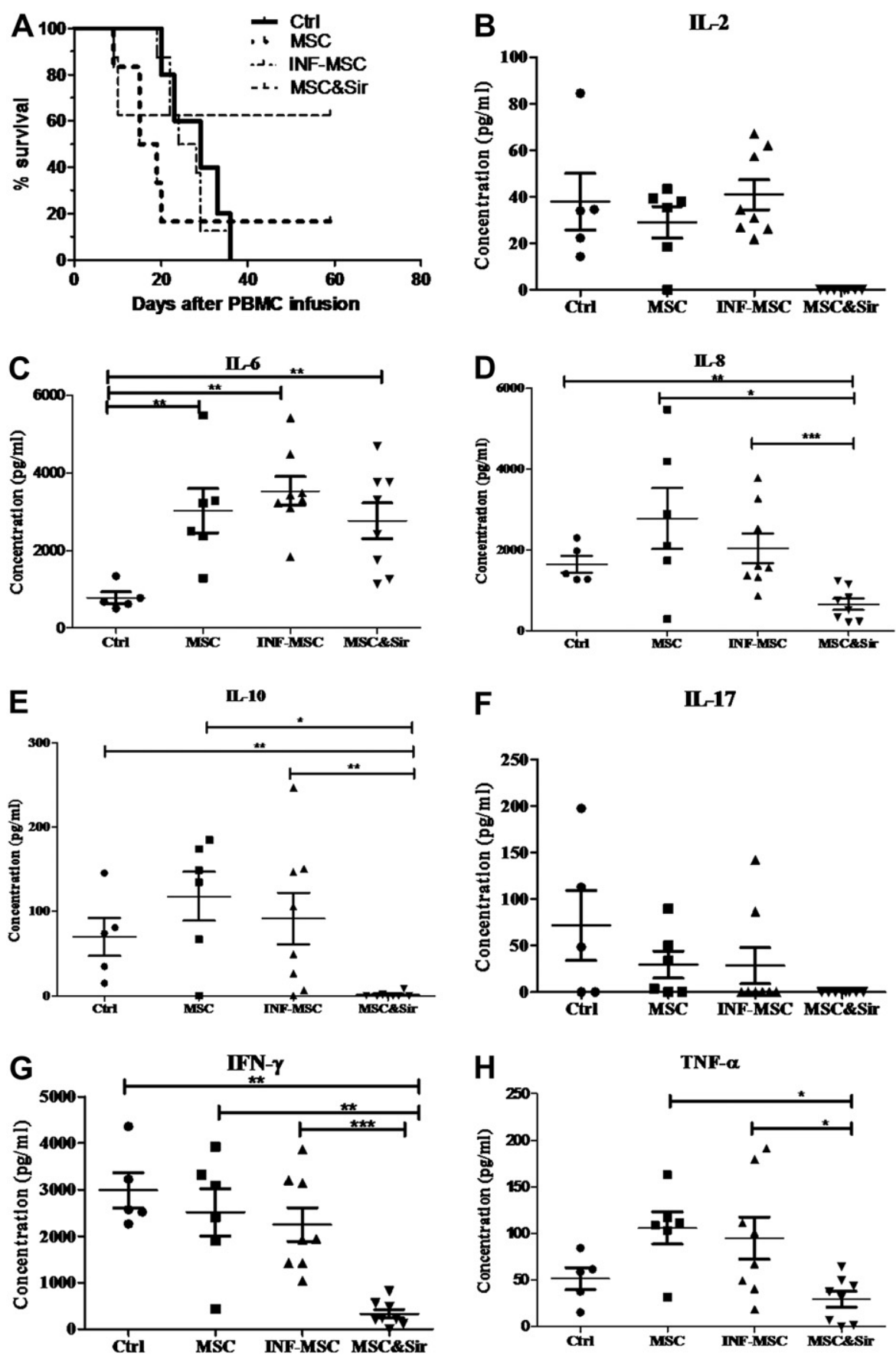

Figure 5. Impact of INF- $\gamma$ activation of MSCs and of administration of sirolimus with MSCs on xenogeneic GVHD and on human serum cytokine levels. NSG mice were irradiated at $2.5 \mathrm{~Gy}$ on day -1 and given $30 \times 10^{6} \mathrm{PBMCs}$ IP on day 0 . Five NSG mice did not receive any MSCs (control mice), six mice were given $3 \times 10^{6}$ MSCs infused IP on days $0,7,14$ and 21 (MSC mice), eight mice were given $3 \times 10^{6}$ MSCs infused IP on days $0,7,14$ and 21 and sirolimus IP $(1.5 \mathrm{mg} / \mathrm{kg}$ from day 0 to day 7 and $1 \mathrm{mg} / \mathrm{kg}$ from day 8 to day 21$)$ after PBMC infusion (MSC\&Sirol mice) and eight mice were given IFN- $\gamma$ activated $3 \times 10^{6}$ MSCs infused IP on days $0,7,14$ and 21 after PBMC infusion (INF-MSC mice). (A) Survival curve. (B-H) Serum cytokine levels on day 8 after PBMC infusion. ${ }^{*} P<0.05, * * P<0.01$, $* * * P<0.001$.

on days $0,7,14$ and 21 after transplantation (INFMSC mice). As shown in Figure 5A, neither infusion of MSCs nor infusion of IFN- $\gamma$ activated MSCs consistently prevented xenogeneic GVHD. However, there was a suggestion for improved survival in MSC\&Sir mice (with five of eight mice surviving beyond day 62). MSC infusion increased the serum levels of IL- 6 on day 8 but had no statistically significant impact on IL-2, IL-8, IL-10, IL-17, TNF- $\alpha$ and IFN- $\gamma$ on that day (serum IL-4 and IL-15 levels were low in all mice groups). In contrast, administration of MSCs together with 
sirolimus resulted in lower serum levels of IL-8, IL-10 and IFN- $\gamma$ (but higher levels of IL-6) compared with control mice and lower levels of IL-8, IL-10, TNF- $\alpha$ and IFN- $\gamma$ compared with MSC mice on day 8 after transplantation. All MSC\&Sir mice had undetectable levels of IL-17 and IL-2.

In a second set of experiments, we investigated whether repeated intravenous infusion of MSC $\left(3 \times 10^{6}\right.$ cells $)$ on days 0,7 and 14 could prevent xenogeneic GVHD in NSG mice given 2.5 Gy TBI on day -1 and human PBMCs $\left(30 \times 10^{6}\right.$ cells $)$ IP on day 0 . Six mice received MSCs a few hours before PBMCs, and five mice received only PBMCs. As observed with intraperitoneal injection of MSCs, intravenous infusion of MSCs failed to prevent GVHD, with MSC/PBMC mice $(\mathrm{n}=6)$ dying on days $6,14,16,19,23$ and 29 after transplantation and control mice $(\mathrm{n}=5)$ dying on days $22,25,25,34$ and 34 . On day 14 , because of the quantity and size of MSCs of GVHD, it was difficult to inject the entire dose of $3 \times 10^{6}$ MSCs. One mouse survived after receiving the complete dose, one mouse died immediately after the injection (possibly because of pulmonary embolism) and a third mouse died 2 days later (also probably secondary to pulmonary embolism because the mouse had a brief cardiac arrest at the time of MSC injection). The three remaining mice were not injected. On day 21, mice were too sick to receive an intravenous injection of MSCs. As observed with IP infusion of MSCs, MSC infused intravenously failed to decrease infiltration by human cells in the blood, bone marrow and spleen (data not shown).

We next analyzed the engraftment and homing of MSCs in NSG mice with xenogeneic GVHD, based on the detection of human SRY by nested PCR. MSC engraftment and homing was analyzed in eight NSG mice irradiated with $2.5 \mathrm{~Gy}$ and given $3 \times 10^{6}$ MSCs derived from male donors on days 0,7 and 14 (total dose $12 \times 10^{6}$ cells) and $30 \times 10^{6} \mathrm{PBMCs}$ from female donors on day 0 , all cells being injected IP. Eight mice were analyzed, and evidence for cells of male origin was demonstrated only in one of the eight mice in the bone marrow and peritoneal fluid on day 19 after transplantation (data not shown).

\section{Discussion}

Studies assessing the ability of MSCs to prevent or to treat acute GVHD in animal models and in humans have yielded conflicting results; however, they have demonstrated that MSCs infused in vivo acted mainly by secreting immunoregulatory agents and not through engraftment and differentiation in tissues affected by GVHD $(30,37)$. These observations have important implications because they stress that factors, such as MSC origin, culture conditions, type of serum used and extent of ex vivo expansion that could affect the MSC secretion profile are also likely to have an impact on the activity of MSCs in vivo. This possibility prompted us to develop two models of xenogeneic GVHD in immunodeficient mice and to test the ability of human MSCs infused IP to prevent xenogeneic GVHD.

In a first step, we developed a model of xenogeneic GVHD in NOD/SCID mice, based on previous work by other groups of investigators in SCID or NOD/SCID mice $(38,39)$. This model induced high levels of human chimerism in the spleen but a lower level in the bone marrow. All tested mice died within the first 30 days after transplantation with evidence of xenogeneic GVHD. However, this model has some limitations, including the high number of human PBMCs needed to induce lethal xenogeneic GVHD and the relatively low percentage of human cells in the bone marrow of transplanted mice. We developed another model of xenogeneic GVHD in a more immunodeficient mouse strain (NSG mice) $(36,40)$. These mice present several advantages compared with other immunodeficient mice because they lack T-, B- and NK-cell function and have reduced macrophage and dendritic cell functions $(36,40)$. As expected, a smaller number of human PBMCs was needed to induce xenogeneic GVHD in this model. This model also allowed reaching higher human chimerism levels in the bone marrow, and all tested mice died with histopathologic and flow cytometry evidence of massive organ infiltration by human cells. These results are consistent with the observations of Ito et al. (41), who reported that intraperitoneal infusion of $1 \times 10^{7}$ human PBMCs induced lethal xenogeneic GVHD in all tested mice and that lower numbers of human PBMCs were needed to induce lethal GVHD in NSG mice than in $\mathrm{NOD} / \mathrm{SCID}$ or BALB/cA-RAG2 $2^{\text {null }}$ mice.

The main observation of the current study was that intraperitoneal bone marrow-derived MSC infusion failed to prevent mortality from xenogeneic GVHD both in the NOD/SCID and in the NSG mouse models, whereas flow cytometry analysis and histology at the time of necropsy revealed similar infiltration by human $\mathrm{T}$ cells and similar frequency of regulatory $\mathrm{T}$ cells in MSC-infused mice and control mice. This observation held true even when multiple infusions of MSCs were performed. These results are in contrast to our in vitro data showing that MSCs, even at low MSC/PBMC ratios, decreased T-cell proliferation [as observed previously by others (9)] and to observations by Tisato et al. (42) showing that intravenous infusion of four doses of MSCs at weekly intervals (total dose, $12 \times 10^{6} \mathrm{MSCs}$ ) prevented the development of xenogeneic GVHD in NOD/SCID 
mice given $2 \times 10^{7}$ human PBMCs intravenously after 2.5 Gy TBI. The discrepancies between the current study and the study by Tisato et al. (42) could be related to the fact that we induced a more aggressive xenogeneic GVHD in our two models by infusing higher numbers of human PBMCs. However, although aggressive, preliminary data from our group suggest that xenogeneic GVHD in NSG mice could be prevented or significantly delayed by the administration of the mammalian target of rapamycin inhibitor sirolimus or by infusion of regulatory $\mathrm{T}$ cells (43), demonstrating that the models developed were not too aggressive to prevent any success in preventing or attenuating GVHD signs. Another possible explanation is that we used bone marrowderived MSCs, whereas Tisato et al. (42) used cord blood-derived MSCs. In vitro inhibition of T-cell proliferation by bone marrow-derived MSCs in the current study was significantly lower than what was observed by Tisato et al. (42) using cord bloodderived MSCs. Further studies comparing the ability of multiple MSC products from multiple sources and culture conditions to attenuate xenogeneic GVHD are needed to identify the best MSC product to test in future large clinical trials.

Activation of MSCs by INF- $\gamma$ did not significantly increase ability of MSCs to prevent xenogeneic GVHD, whereas five of eight mice given MSCs and a 21-day administration of sirolimus survived beyond day 62 after transplantation. Further studies are needed to determine whether sirolimus and MSCs are synergistic (or not) to prevent xenogeneic GVHD, although the survival rate in MSC\&Sir mice in the current study seems comparable to what we have previously observed with sirolimus administration alone (43).

Infusion of MSCs resulted in increased serum levels of IL-6 (in agreement with the large secretion of IL- 6 by MSCs in vitro [31]) but had no statistically significant impact on IL-2, IL-17, TNF- $\alpha$ or IFN- $\gamma$ levels. In contrast, sirolimus administration in MSC mice resulted in lower levels of IL-8, IL-10, TNF- $\alpha$ and IFN- $\gamma$ compared with MSC mice given MSC but no sirolimus, demonstrating the impact of sirolimus administration on cytokine serum levels as observed by other investigators (44).

We chose to infuse MSCs mainly IP to avoid the risk of pulmonary embolism associated with intravenous infusion of large amounts of MSCs and to avoid direct homing of the MSCs to the lungs, which is one of the targets of xenogeneic GVHD. This route of MSC administration has been shown to be effective in a murine model of GVHD (17). We observed that MSCs infused IP in NOD/SCID mice were able to migrate into several organs including bone marrow. However, we failed to demonstrate
DNA of MSC donor origin at the sites of xenogeneic GVHD in NSG mice infused with human PBMCs and human MSCs, despite the use of a sensitive technique. This observation is in agreement with the current thinking that MSCs do not prevent GVHD through engraftment and differentiation at the sites targeted by GVHD (30). Finally, similar to what was observed with intraperitoneal infusion, intravenous infusion of MSCs also did not prevent GVHD in the two tested mouse models.

In conclusion, we have developed two robust models of xenogeneic GVHD. Although MSC infusions failed to prevent xenogeneic GVHD in these two models, further studies are needed to investigate whether modulation of MSC secretion activity (i.e., by transfecting the cells with inhibitory cytokine genes (45) or by using MSCs obtained from other sources or after other culture conditions optimized for in vitro immunosuppression) could increase efficacy of MSCs in prevention of xenogeneic GVHD.

\section{Acknowledgments}

This study was supported by funds from the National Fund for Scientific Research (FNRS), the fund Leon Fredericq and Anti-Cancer Center at the University of Liège and the Belgian Federation Against Cancer. $\mathrm{FBr}, \mathrm{LB}$ and $\mathrm{MH}$ are Télévie Research Assistants, SHB is postdoctoral researcher and FBa is senior research associate of the National Fund for Scientific Research (FNRS) Belgium. We are very grateful to Pierre Drion for his help with the mouse experiments and to Sandra Ormenese from the Imaging and Flow Cytometry Platform of the GIGA for help with flow cytometry analyses. We are also grateful to Olivier Dengis, Amélie Halleux and Coline Daulne for excellent technical assistance.

Author contributions are as follows: study design, $\mathrm{FBr}, \mathrm{LB}, \mathrm{SHB}, \mathrm{AB}, \mathrm{FBa}$; MSC differentiation, FBr, $\mathrm{CL}, \mathrm{AB}, \mathrm{YB}$; mice experiments, $\mathrm{FBr}, \mathrm{LB}, \mathrm{MH}, \mathrm{SD}$, SHB, SR, TCR $\mathrm{V}_{\beta}$ analyses, EC; flow cytometry analyses, $\mathrm{FBr}, \mathrm{LB}$; histology, LdL; data analyses, $\mathrm{FBr}, \mathrm{LB}$; manuscript editing, LB, LdL, EC, SR, YB, $\mathrm{AB}$; approval of the manuscript, all authors; writing of article, $\mathrm{FBr}$ and $\mathrm{FBa}$.

Disclosure of interest: The authors have no commercial, proprietary or financial interest in the products or companies described in this article.

\section{References}

1. Deeg HJ. How I treat refractory acute GVHD. Blood. 2007; 109:4119-26.

2. Baron F, Maris MB, Sandmaier BM, Storer BE, Sorror M, Diaconescu R, et al. Graft-versus-tumor effects after 
allogeneic hematopoietic cell transplantation with nonmyeloablative conditioning. J Clin Oncol. 2005;23: 1993-2003.

3. Reddy P, Arora M, Guimond M, Mackall CL, Weisdorf D. GVHD: a continuing barrier to the safety of allogeneic transplantation. Biol Blood Marrow Transplant. 2009;15:162-8.

4. Baron F, Labopin M, Niederwieser D, Vigouroux S, Cornelissen JJ, Malm C, et al. Impact of graft-versus-host disease after reduced-intensity conditioning allogeneic stem cell transplantation for acute myeloid leukemia: a report from the Acute Leukemia Working Party of the European group for blood and marrow transplantation [published online ahead of print May 22, 2012]. Leukemia.

5. Ho VT, Soiffer RJ. The history and future of T-cell depletion as graft-versus-host disease prophylaxis for allogeneic hematopoietic stem cell transplantation. Blood. 2001;98: 3192-204.

6. Pittenger MF, Mackay AM, Beck SC, Jaiswal RK, Douglas R, Mosca JD, et al. Multilineage potential of adult human mesenchymal stem cells. Science. 1999;284:143-7.

7. Noort WA, Kruisselbrink AB, In't Anker PS, Kruger M, van Bezooijen RL, de Paus RA, et al. Mesenchymal stem cells promote engraftment of human umbilical cord blood-derived CD34(+) cells in NOD/SCID mice. Exp Hematol. 2002;30: 870-8.

8. Di Nicola M, Carlo-Stella C, Magni M, Milanesi M, Longoni PD, Matteucci P, et al. Human bone marrow stromal cells suppress T-lymphocyte proliferation induced by cellular or nonspecific mitogenic stimuli. Blood. 2002;99:3838-43.

9. Le Blanc K, Tammik L, Sundberg B, Haynesworth SE, Ringden $\mathrm{O}$. Mesenchymal stem cells inhibit and stimulate mixed lymphocyte cultures and mitogenic responses independently of the major histocompatibility complex. Scand J Immunol. 2003;57:11-20.

10. Krampera M, Glennie S, Dyson J, Scott D, Laylor R, Simpson E, et al. Bone marrow mesenchymal stem cells inhibit the response of naive and memory antigen-specific $\mathrm{T}$ cells to their cognate peptide. Blood. 2003;101:3722-9.

11. Le Blanc K, Ringden O. Immunobiology of human mesenchymal stem cells and future use in hematopoietic stem cell transplantation. Biol Blood Marrow Transplant. 2005;11:321-34.

12. Le Blanc $\mathrm{K}$, Ringden O. Immunomodulation by mesenchymal stem cells and clinical experience. J Intern Med. 2007; 262:509-25.

13. Nauta AJ, Fibbe WE. Immunomodulatory properties of mesenchymal stromal cells. Blood. 2007;110:3499-506.

14. Bartholomew A, Sturgeon C, Siatskas M, Ferrer K, McIntosh K, Patil S, et al. Mesenchymal stem cells suppress lymphocyte proliferation in vitro and prolong skin graft survival in vivo. Exp Hematol. 2002;30:42-8.

15. Yanez R, Lamana ML, Garcia-Castro J, Colmenero I, Ramirez M, Bueren JA. Adipose tissue-derived mesenchymal stem cells have in vivo immunosuppressive properties applicable for the control of the graft-versus-host disease. Stem Cells. 2006;24:2582-91.

16. Polchert D, Sobinsky J, Douglas G, Kidd M, Moadsiri A, Reina E, et al. IFN-gamma activation of mesenchymal stem cells for treatment and prevention of graft versus host disease. Eur J Immunol. 2008;38:1745-55.

17. Christensen ME, Turner BE, Sinfield LJ, Kollar K, Cullup H, Waterhouse NJ, et al. Mesenchymal stromal cells transiently alter the inflammatory milieu post-transplant to delay graftversus-host disease. Haematologica. 2010;95:2102-10.

18. Sudres M, Norol F, Trenado A, Gregoire S, Charlotte F, Levacher B, et al. Bone marrow mesenchymal stem cells suppress lymphocyte proliferation in vitro but fail to prevent graft-versushost disease in mice. J Immunol. 2006;176:7761-7.
19. Prigozhina TB, Khitrin S, Elkin G, Eizik O, Morecki S, Slavin S. Mesenchymal stromal cells lose their immunosuppressive potential after allotransplantation. Exp Hematol. 2008;36:1370-6.

20. Badillo AT, Peranteau WH, Heaton TE, Quinn C, Flake AW. Murine bone marrow derived stromal progenitor cells fail to prevent or treat acute graft-versus-host disease. Br J Haematol. 2008;141:224-34.

21. Mielcarek M, Storb R, Georges GE, Golubev L, Nikitine A, Hwang B, et al. Mesenchymal stromal cells fail to prevent acute graft-versus-host disease and graft rejection after dogleukocyte-antigen haploidentical bone marrow transplantation. Biol Blood Marrow Transplant. 2011;17:214-25.

22. Miura M, Miura Y, Padilla-Nash HM, Molinolo AA, Fu B, Patel V, et al. Accumulated chromosomal instability in murine bone marrow mesenchymal stem cells leads to malignant transformation. Stem Cells. 2006;24:1095-103.

23. Meisel R, Brockers S, Heseler K, Degistirici O, Bulle H, Woite $\mathrm{C}$, et al. Human but not murine multipotent mesenchymal stromal cells exhibit broad-spectrum antimicrobial effector function mediated by indoleamine 2,3-dioxygenase. Leukemia. 2011;25:648-54.

24. Ball LM, Bernardo ME, Roelofs H, Lankester A, Cometa A, Egeler RM, et al. Cotransplantation of ex vivo expanded mesenchymal stem cells accelerates lymphocyte recovery and may reduce the risk of graft failure in haploidentical hematopoietic stem-cell transplantation. Blood. 2007;110:2764-7.

25. Le Blanc K, Frassoni F, Ball L, Locatelli F, Roelofs H, Lewis I, et al. Mesenchymal stem cells for treatment of steroid-resistant, severe, acute graft-versus-host disease: a phase II study. Lancet. 2008;371:1579-86.

26. Ning $H$, Yang $F$, Jiang $M, H u L$, Feng $K$, Zhang J, et al. The correlation between cotransplantation of mesenchymal stem cells and higher recurrence rate in hematologic malignancy patients: outcome of a pilot clinical study. Leukemia. 2008;22: 593-9.

27. Bernardo ME, Ball LM, Cometa AM, Roelofs H, Zecca M, Avanzini MA, et al. Co-infusion of ex vivo-expanded, parental MSCs prevents life-threatening acute GVHD, but does not reduce the risk of graft failure in pediatric patients undergoing allogeneic umbilical cord blood transplantation. Bone Marrow Transplant. 2011;46:200-7.

28. Baron F, Lechanteur C, Willems E, Bruck F, Baudoux E, Seidel L, et al. Cotransplantation of mesenchymal stem cells might prevent death from graft-versus-host disease (GVHD) without abrogating graft-versus-tumor effects after HLAmismatched allogeneic transplantation following nonmyeloablative conditioning. Biol Blood Marrow Transplant. 2010;16:838-47.

29. Martin PJ, Uberti JP, Soiffer RJ, Klingemann H, Waller EK, Daly AS, et al. Prochymal improves response rates in patients with steroid-refractory acute graft versus host disease (SRGVHD) involving the liver and gut: results of a randomized, placebo-controlled, multicenter phase III trial in GVHD. Biol Blood Marrow Transplant. 2010;16(Suppl. 2):S169-70.

30. Horwitz EM, Maziarz RT, Kebriaei P. MSCs in hematopoietic cell transplantation. Biol Blood Marrow Transplant. 2011;17(1 Suppl.):S21-9.

31. Briquet A, Dubois S, Bekaert S, Dolhet M, Beguin Y, Gothot A. Prolonged ex vivo culture of human bone marrow mesenchymal stem cells influences their supportive activity toward NOD/SCID-repopulating cells and committed progenitor cells of B lymphoid and myeloid lineages. Haematologica. 2010;95:47-56.

32. Pirson L, Baron F, Meuris N, Giet O, Castermans E, Greimers R, et al. Despite inhibition of hematopoietic progenitor cell growth in vitro, the tyrosine kinase inhibitor 
imatinib does not impair engraftment of human CD133+ cells into NOD/SCIDbeta2mNull mice. Stem Cells. 2006;24: 1814-21.

33. Lo YM, Tein MS, Lau TK, Haines CJ, Leung TN, Poon PM, et al. Quantitative analysis of fetal DNA in maternal plasma and serum: implications for noninvasive prenatal diagnosis. Am J Hum Genet. 1998;62:768-75.

34. Castermans E, Baron F, Willems E, Schaaf-Lafontaine N, Meuris N, Gothot A, et al. Evidence for neo-generation of T cells by the thymus after non-myeloablative conditioning. Haematologica. 2008;93:240-7.

35. Castermans E, Hannon M, Dutrieux J, Humblet-Baron S, Seidel L, Cheynier R, et al. Thymic recovery after allogeneic hematopoietic cell transplantation with non-myeloablative conditioning is limited to patients younger than 60 years of age. Haematologica. 2011;96:298-306.

36. Ito M, Hiramatsu H, Kobayashi K, Suzue K, Kawahata M, Hioki K, et al. NOD/SCID/gamma(null)(c) mouse: an excellent recipient mouse model for engraftment of human cells. Blood. 2002;100:3175-82.

37. Baron F, Storb R. Mesenchymal stromal cells: a new tool against graft-versus-host disease? Biol Blood Marrow Transplant. 2012;18:822-40.

38. Tsuchida M, Brown SA, Tutt LM, Tan J, Seehafer DL, Harris JP, et al. A model of human anti-T-cell monoclonal antibody therapy in SCID mice engrafted with human peripheral blood lymphocytes. Clin Transplant. 1997;11: $522-8$.

39. Sandhu JS, Gorczynski R, Shpitz B, Gallinger S, Nguyen HP, Hozumi N. A human-model of xenogeneic graft-versus-host disease in SCID mice engrafted with human peripheral-blood lymphocytes. Transplantation. 1995;60:179-84.
40. Hiramatsu H, Nishikomori R, Heike T, Ito M, Kobayashi K, Katamura $\mathrm{K}$, et al. Complete reconstitution of human lymphocytes from cord blood CD34(+) cells using the NOD/ SCID/gamma c(null) mice model. Blood. 2003;102:873-80.

41. Ito R, Katano I, Kawai $\mathrm{K}$, Hirata $\mathrm{H}$, Ogura $\mathrm{T}$, Kamisako $\mathrm{T}$, et al. Highly sensitive model for xenogenic GVHD using severe immunodeficient NOG mice. Transplantation. 2009; $87: 1654-8$.

42. Tisato V, Naresh K, Girdlestone J, Navarrete C, Dazzi F. Mesenchymal stem cells of cord blood origin are effective at preventing but not treating graft-versus-host disease. Leukemia. 2007;21:1992-9.

43. Bruck F, Baron F, Dubois S, Briquet A, Hanon-Absil M, Belle L, et al. Rapamycin delays xenogeneic acute graft versus host disease (AGVHD) in NOD/SCID/Il2R gamma null (NSG) mice: impact of regulatory $\mathrm{T}$ cells. Biol Blood Marrow Transplant. 2011;17:S332.

44. Yoshizaki A, Yanaba K, Yoshizaki A, Iwata Y, Komura K, Ogawa $\mathrm{F}$, et al. Treatment with rapamycin prevents fibrosis in tight-skin and bleomycin-induced mouse models of systemic sclerosis. Arthritis Rheum. 2010;62:2476-87.

45. Min CK, Kim BG, Park G, Cho B, Oh IH. IL-10-transduced bone marrow mesenchymal stem cells can attenuate the severity of acute graft-versus-host disease after experimental allogeneic stem cell transplantation. Bone Marrow Transplant. 2007;39:637-45.

\section{Supplementary data}

Supplementary data related to this article can be found at http://dx.doi.org/10.1016/j.jcyt.2012.09.003 


\section{3.e1 F. Bruck et al.}

\section{Methods}

Detection and quantification of engraftment of MSCs in NOD/SCID mice

The 2-month-old NOD/SCID mice were irradiated with $3.0 \mathrm{~Gy}$ TBI using ${ }^{137} \mathrm{Cs}$ source 1 day before passage 3 intraperitoneal infusion of $2.10^{6}$ MSCs. Mice received $20 \mu \mathrm{L}$ of aASGM1 antiserum IP 1 day before injection and 8 days after transplantation. After 24 h, 7 days or 15 days, mice were killed, and lungs, liver, kidneys, small intestine, spleen, bone marrow and peripheral blood were collected and frozen. Homing of MSCs was studied through realtime quantitative PCR (TaqMan technology and ABI PRISM 7700; Altera). Genomic DNA for PCR analysis was prepared from mice tissues using the DNeasy Blood \& Tissue Kit (Qiagen, Valencia, CA, USA) after overnight incubation at $56^{\circ} \mathrm{C}$ in lysis buffer with proteinase $\mathrm{K}$ as according to the manufacturer's instructions. The DNA concentration and purity were estimated by optical density measurement using NanoDrop 1000 (Thermo Fisher Scientific, Wilmington, DE, USA). Using Power
SYBR Green PCR master mix (Applied Biosystems, Foster City, CA, USA), 100 ng of purified DNA from various tissues was amplified. The target gene was human albumin, forward primer was TGAAACATACGTTCCCAAAGAGTTT and reverse primer was CTCTCCTTCTCAGAAAGTG TGCATAT. As internal control, endogenous mouse $\beta$-actin gene was amplified. The primers for mouse $\beta$-actin gene were forward primer CCTGTGGCA TCCATGAAACTAC and reverse primer CACT GTGTTGGCATAGAGGTCTTT. The relative quantity of human albumin gene was calculated by threshold cycle Ct value. No cross-reactivity between human and murine genomic DNA was observed when amplification of human albumin or murin $\beta$-actin was performed with our primer set. We performed a validation experiment to demonstrate that efficiencies of target and reference were approximately equal. The absolute value of the slope of $\log$ input amount versus Ct was $<0.1$ as recommended by Applied Biosystems. Supplementary Table I describes the homing of MSCs into various organs. 
A

PBMC alone

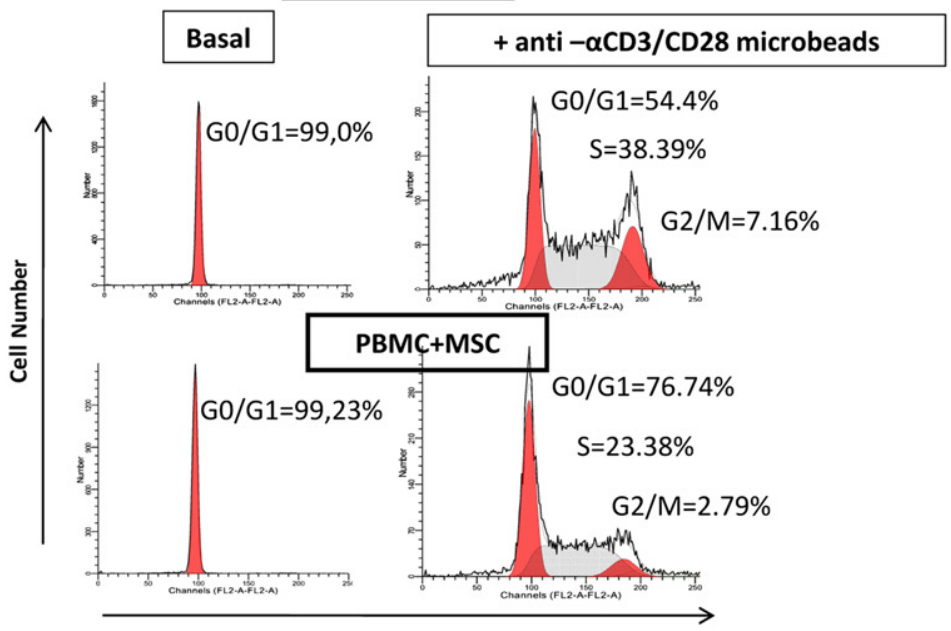

B
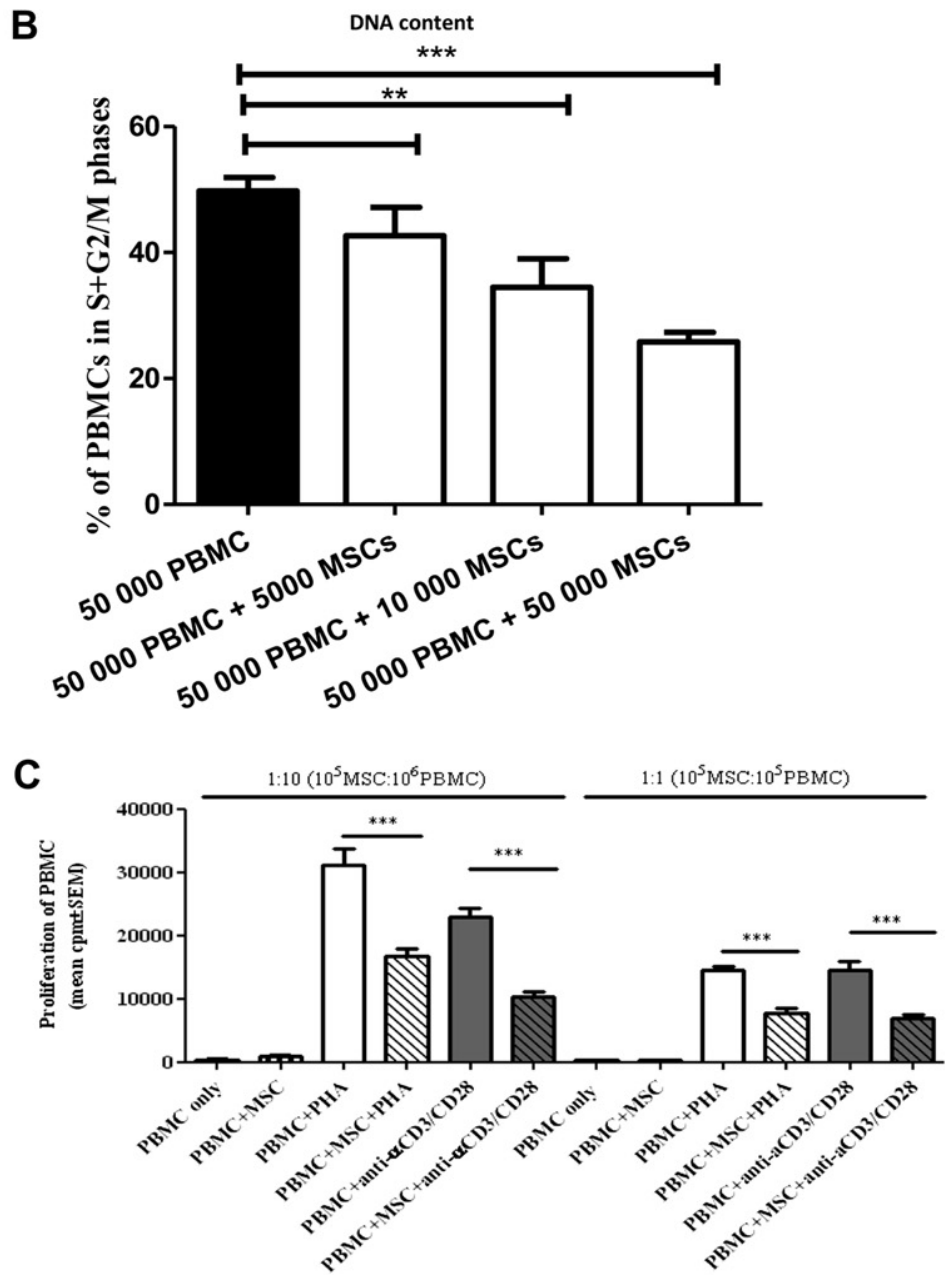

Supplementary Figure 1. Inhibition of PBMC proliferation by third party MSC. (A) Representative histograms of PBMC in different phases of the cell cycle obtained with ModFit software. Left histograms represent the cell cycle of PBMCs alone or with MSCs used as negative controls, and right histograms represent PBMCs stimulated with anti- $\alpha \mathrm{CD} 3 / \mathrm{CD} 28$ microbeads without or with MSCs. (B) During 4 days, 50 000 PBMCs were stimulated with anti- $\alpha$ CD3/CD28 microbeads with or without irradiated (25 Gy) MSCs (10, 2 or 1 PBMC/MSC ratios) added at the beginning of the culture. Proliferation was assessed by analysis of the cell cycle by flow cytometry. Results of five independent experiments were expressed as the mean ( \pm standard error of the mean) of the percentages of cells present in $S+G_{2} M$ phases. ${ }^{*} P<.05$. $(C)$ PBMC proliferation assessed with ${ }^{3}[\mathrm{H}]$-thymidine incorporation. Stimulation of $1 \times 10^{5}$ or $1 \times 10^{6}$ PBMCs was achieved with anti- $\alpha \mathrm{CD} 3 /$ CD28 microbeads or phytohemagglutinin $(10 \mu \mathrm{g} / \mathrm{mL})$ with or without added irradiated $(25 \mathrm{~Gy})$ MSCs $\left(1 \times 10^{5}\right.$ cells $) .{ }^{3}[\mathrm{H}]-\mathrm{Thymidine}$ incorporation was measured after 4 days of culture, and data were expressed as mean counts per minute $( \pm$ SEM). Data from six independent experiments are presented. 


\section{3.e3 F. Bruck et al.}
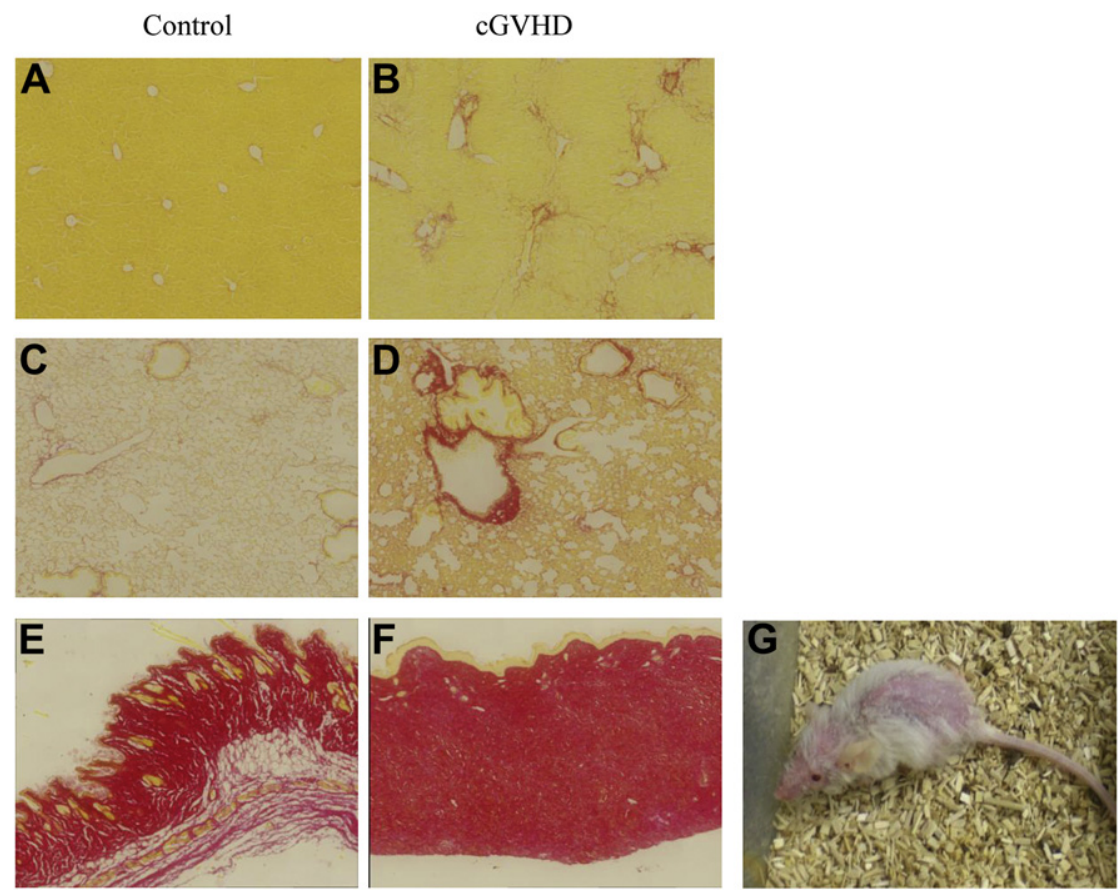

Supplementary Figure 2. (A-G) Chronic GVHD in NSG mice. The NSG mouse who survived $>100$ days after intraperitoneal infusion of human PBMCs and MSCs had signs of chronic GVHD with a fur loss that started from day 60. (A) Liver, (C) lungs, and (E) skin of a control NSG mouse. (B) Liver of the mouse with chronic GVHD showing extensive collagen filaments. (D) Lungs of the mouse with chronic GVHD showing high amounts of collagen around blood vessels. (F) Lungs of the mouse with chronic GVHD showing skin collagen extending into the subcutaneous fatty tissue. (Original pictures captured with microscope FSX 100 (Olympus, Aartselaar, Belgium) at 20× magnification). (G) Picture on day 126 after transplantation of the mouse that died 136 days after PBMC and repeated MSC transplantation. This mouse presented signs of chronic GVHD such as a significant loss of fur and skin fibrosis.

Supplementary Table I. Homing of mesenchymal stromal cells injected intraperitoneally in NOD/SCID mice.

\begin{tabular}{|c|c|c|c|c|c|c|c|c|c|c|c|}
\hline & \multicolumn{3}{|c|}{$\begin{array}{l}1 \text { Day after MSC } \\
\text { intraperitoneal infusion }\end{array}$} & \multicolumn{4}{|c|}{$\begin{array}{c}7 \text { Days after MSC intraperitoneal } \\
\text { infusion }\end{array}$} & \multicolumn{4}{|c|}{$\begin{array}{c}14 \text { Days after MSC intraperitoneal } \\
\text { infusion }\end{array}$} \\
\hline & M. \#1 & M. \#2 & M. \#3 & M. \#1 & M. \#2 & M. \#3 & M. \#4 & M. \#1 & M. \#2 & M. \#3 & M. \#4 \\
\hline $\mathrm{BM}$ & - & - & - & ++ & + & + & ++ & ++ & - & ++ & + \\
\hline Liver & - & + & - & ++ & - & - & - & - & - & - & - \\
\hline Lungs & - & - & - & - & - & ++ & - & - & - & - & - \\
\hline Spleen & - & +++ & - & - & - & +++ & +++ & - & - & + & + \\
\hline Small bowel & + & - & - & ++ & + & - & - & - & - & - & - \\
\hline Kidney & - & + & - & +++ & ++ & - & - & - & ++ & +++ & - \\
\hline
\end{tabular}

,$+++ \Delta \mathrm{CT}-12$ to $-16 ;++, \Delta \mathrm{CT}-16$ to $-17 ;+, \Delta \mathrm{CT}-17$ to -18 .

$\Delta \mathrm{CT}$, delta cycle threshold; BM, bone marrow; M., mice; MSC, mesenchymal stromal cell. 